\title{
Influence of Karst Caves at Pile Side on the Bearing Capacity of Super-Long Pile Foundation
}

\author{
Peisen Wang, ${ }^{1,2,3}$ Hongyan Ding, ${ }^{1,3}$ and Puyang Zhang $\mathbb{D}^{1,3}$ \\ ${ }^{1}$ State Key Laboratory of Hydraulic Engineering Simulation and Safety, Tianjin University, Tianjin 300072, China \\ ${ }^{2}$ School of Civil Engineering, Shandong Jianzhu University, No. 1000 Fengming Road, Jinan 250101, China \\ ${ }^{3}$ School of Civil Engineering, Tianjin University, No. 92 Weijin Road Nankai District, Tianjin 300072, China \\ Correspondence should be addressed to Puyang Zhang; zpy_td@163.com
}

Received 28 October 2019; Revised 28 January 2020; Accepted 15 February 2020; Published 11 March 2020

Academic Editor: Nhon Nguyen-Thanh

Copyright ( 92020 Peisen Wang et al. This is an open access article distributed under the Creative Commons Attribution License, which permits unrestricted use, distribution, and reproduction in any medium, provided the original work is properly cited.

The differences in development and situation of karst caves lead to two kinds of karst caves, and the karst cave may be on the pile side or at the pile bottom, which has a different influence on the bearing capacity of pile foundation. The paper presents a numerical analysis of the influence of karst caves at pile side on the bearing capacity of super-long pile foundation in karst areas. According to the size of pile foundation of a real bridge project, this paper modelized karst caves and investigated the karst cave from the effect of length, height, and thickness of roof on horizontal and vertical bearing capacity of pile foundation. The main conclusions can be drawn as: when the horizontal displacement at the top of pile foundation is greater than $0.05 \mathrm{~m}$, the horizontal load is correlated positively with the length of karst cave; when the vertical displacement is greater than $0.07 \mathrm{~m}$, the vertical load is correlated negatively with the thickness of the roof of karst cave. However, the height of karst cave has little effect on the bearing capacity; also the existence of karst cave has little influence on the dynamic response of pile foundation. The results of this study can be important with reference to the design and construction of pile foundations in karst areas.

\section{Introduction}

The bearing capacity of pile foundations in karst areas is significantly from that in common areas. However, current technical codes are mainly applicable to common areas, which are difficult to meet the actual requirements of pile foundations in karst areas due to its particularity and complexity. When the designed bearing capacity of pile foundations in karst areas cant meet the actual need, it will cause great loss to practical engineering. On the contrary, if the designed bearing capacity of pile foundations is too conservative, it will cause a huge waste, thus greatly increasing the project cost. Therefore, it is of great significance to study the influence of karst cave on the bearing capacity of pile foundation in order to ensure the safety and reliability of pile foundations design and construction in karst areas and reduce the project cost. Also, it will provide enormous guiding significance and bring huge benefits for the design and construction of pile foundations in the vast karst areas $[1,2]$.
With the continuous development of infrastructure in China, more and more railways and highways pass through karst areas. For example, the 47\# pier of Yellow River Bridge in Pingyin along Taian-Donger Expressway is in limestone karst, where the karst fissures are serious with the depth of karst caves being mostly below $80 \mathrm{~m}$ of the surface, and the height being mostly over 5 meters. It has been found that nine (accounting for $18 \%$ of the total) piles existing karst caves within 10 meters below the pile bottom and the size of karst caves varying from 1 to 14.3 meters. Pile foundation is one of the most effective treatment methods to improve the bearing capacity of the karst area. In this case, the deep pile foundations are most commonly used in practical engineering, such as highways, railways, water conservancy, and other projects, since it can adapt to various types of geological, engineering, and load conditions. The calculation of bearing capacity and settlement of pile foundations involves many factors, such as the geometric size of pile group (including pile spacing, pile length, pile number, ratio of pile 
width to pile length, and so on), pile-forming technology, types and properties of the soil around piles, change of soil profile, load magnitude and duration, and so on.

It can be seen from the existing literature that the construction of large-scale bridges, high-rise buildings, and heavy-duty buildings is generally required to place the foundations deep on the bedrock. Therefore, the rocksocketed pile becomes one of the most adopted forms of foundations in karst areas because of its unique advantages. The widespread application of rock-socketed pile foundations makes researchers pay more attention to study its vertical bearing capacity in karst areas. In terms of the design and construction of practical projects, the pile foundations in karst areas are generally considered to be a common rocksocketed pile. The bearing mechanism of rock-socketed piles in karst areas is obviously different from that of common ones. However, the influence of the existence of "cavities" on the bearing capacity of rock-socketed piles in karst areas is rarely studied. As a result, the study of pile foundations in karst areas has not formed a systematic theory to guide practice engineering [3-6].

Chen et al. conducted a numerical simulation of pile foundation in karst areas and studied the effect of amount, size, and interval of karst caves on bearing characteristics of pile foundation, pointing out that the number of karst caves is positively correlated with the negative friction of pile foundation [7]. In recent years, researchers have carried out the corresponding studies to improve the calculation model and the determination method of parameters according to the theoretical analysis method of the dynamic response of pile foundation and carry out the dynamic analysis of bridge structure based on multipile foundation model [8-11]. Tang et al. [12] conducted vibration table tests with laminar shear box to study the dynamic response of reinforced concrete piles behind wharf bank wall under the effect of liquefied lateral soil flow and presented the significance of large-scale test for the further study of response evaluation of pile foundation under the condition of liquefied site.

Suzuki et al. [13] conducted vibration table tests with cylindrical laminar shear box in the E-defense Laboratory of Japan, studied the influencing factors of pile stress distribution during earthquake, and concluded that when the natural frequency of superstructure is less than or close to that of soil, the inertia force of superstructure plays a major role in controlling pile stress; when the natural frequency of superstructure is much bigger than that of soil, the inertia force of superstructure is small enough that the pile stress is mainly affected by the displacement of soil.

Based on a major infrastructure project, various factors affecting the bearing capacity of pile foundation in karst area is first studied in the present paper, and then the vertical and lateral bearing characteristics of piles and the seismic dynamic characteristics of piles with different distribution laws of karst caves around piles are investigated, which results can be adopted to improve the safety of dynamic response of pile foundations in major infrastructure projects and reveal the law of dynamic response of pile foundations under horizontal earthquakes in karst areas.

\section{Numerical Analysis}

2.1. Purpose of Numerical Analysis. Geotechnical engineering mainly refers to the study of engineering in the underground space, whose special conditions contribute to its particularity. Compared with structural engineering and road engineering, it has the following characteristics:

(1) The geological environment is the main factor affecting the mechanical properties of geotechnical engineering.

(2) The geological environment is also the load-supporting element of geotechnical engineering.

At present, the studies on the tests of pile foundation in karst areas are almost based on specific engineering examples and geological conditions, which are not systematic or universal. The relevant theories of pile foundation projects in karst areas need further study. Due to the complexity of engineering characteristics in the karst area, it is difficult to generate regular results only by indoor test or field test of several piles to fully reflect the influence of various factors on the mechanical characteristics of the pile foundation in karst areas. To comprehensively reflect the influence of different factors on the mechanical properties of the pile foundations in karst areas, it is necessary to conduct related researches by using the $\mathrm{FE}$ method [14-17].

2.2. Pile-Rock Load Transfer Mechanism. In early projects, rock-socketed piles were generally considered as endbearing piles; however, current studies indicated that the lateral resistance of rock-socketed piles generates a great impact on the bearing capacity of pile foundations. In many cases, rock-socketed piles act as the main counterforce to balance the external loads, so they can be regarded as friction piles or end-bearing friction piles. Despite the above understanding, the resistance mode and mechanism are still an open question, which makes it difficult for the design of pile foundations. The wide application of rock-socketed piles with large diameters makes it necessary to study the bearing mechanism and load transfer mechanism between piles and rocks, which can make the design of pile foundations in karst areas more reasonable.

As to the rock-socketed section of the pile body and the surrounding rock mass, when the shear stress on their contact surface is less than the shear strength, they are fully bonded together and should satisfy the coordinated relationship between deformation and stress. Therefore, elasticity and shear lag model theory can be adapted to study the interface characteristics. The expression of the axial force of a single pile is as follows [18]:

$$
\sigma^{\prime}(z)=\frac{P}{\pi a^{2}}\left[\cosh (k z)+\frac{\alpha-\cosh (k l)}{\sinh (k l)} \sinh (k z)\right],
$$

where $P$ is external load acting on the top of the rocksocketed pile; $L$ is Depth of the rock-socketed section of the rock-socketed pile; $\alpha$ is the proportion of external load shared by pile end. 
The corresponding formula of shear stress distribution between the pile and surrounding rock mass is as follows:

$$
\tau(z)=\frac{k P}{2 \pi a}\left[\sinh (k z)+\frac{\alpha-\cosh (k l)}{\sinh (k l)} \cosh (k z)\right] .
$$

For the pile under axial load in ideal condition, formulas (1) and (2) can be used to calculate the axial force and shear stress widely [18]. But this paper focuses on the bearing capacity of pile foundations in karst areas and the existing formulas are not suitable. To solve this kind of complex problem, the FE analyses were taken in this paper.

\section{Model Establishment and Parameter Selection}

3.1. Hypothesis and Simplification of Calculation Model. In practical projects, the loads born by the piles often caused by the combined effects of various factors, such as the weight of the upper structure, water pressure, soil pressure, wind load, and so on. In simulation analysis, it is difficult to take all the factors into account, so the most important influencing factors are needed to be found for analysis. In addition, the karst caves in different places have different forms, not only in size and shape $[19,20]$ but also in the location of the caves and the fillings in the caves. Therefore, in order to make the model established more representative, the calculation model should be simplified as follows:

(1) Piles are only affected by vertical loads.

(2) Only the static loads are considered, while the influence of circulation loads and cyclic loads is not taken into consideration.

(3) The soil on the top of the karst caves is assumed to be isotropic as this study mainly focuses on the influence of cave size on bearing capacity of the pile. Therefore, the variation of the soil property is not taken into consideration.

(4) The rock mass around the karst caves is considered to be continuous, and the surrounding rocks of the karst caves are regarded as a homogeneous isotropic infinite body in the underground semispace. Also, the karst caves maintain certain stability in the natural state.

(5) The caves are regarded as rectangular ones. The shapes of the karst cave are complex in actual projects $[21,22]$. In the previous studies (simulations or tests) of karst cave, some researchers chose a rectangular cave $[23,24]$, and some chose spherical cave for analysis [22]. Based on the previous studies, the rectangular cave is reasonable for the analysis of bearing capacity. Since the mechanical properties of the cave filler are relatively low compared with those of the rock, which generally does not bear stress, they are calculated as empty karst caves.
(6) This paper only takes the bearing characteristics of pile foundations when there is only a single karst cave and the pile foundation passes through the karst cave, without considering the interaction of multiple karst caves.

3.2. FE Model. According to the report on the geological survey of the soil under No. 47 cap, the thickness of quaternary soil was about $80 \mathrm{~m}$, with the length and diameter of the pile being $100 \mathrm{~m}$ and $2 \mathrm{~m}$, and the length, width, and thickness of the cap being $45 \mathrm{~m}, 12 \mathrm{~m}$, and $2 \mathrm{~m}$, respectively. Therefore, the ranges of height, length, and roof thickness of the fixed cave should be $1-15 \mathrm{~m}, 4-20 \mathrm{~m}$, and $1-10 \mathrm{~m}$, respectively. When the pile foundation passes through the cave, the distance between the cave bottom and the pile bottom is $1-6 \mathrm{~m}$; when the pile foundation does not pass through the cave, the distance between the cave top and the pile bottom is $1-6 \mathrm{~m}$. Typical three-dimensional karst cave and the distribution of karst caves around piles are displayed in Figure 1.

In the previous studies [25-27], if the section size of soil is ten times than that of the pile, the influence of the boundary effect of soil can be ignored. Considering the diameter of the pile analyzed in this paper is 2 meters, the diameter of soil was chosen as 40 meters to eliminate boundary effects of soil in the analysis method. The depth of the FE model is $h=120 \mathrm{~m}$, in which the thickness of the overlying soil layer is $80 \mathrm{~m}$, and that of the underlying rock layer is $40 \mathrm{~m}$. The analysis model is shown in Figure 2. In the FE models, the 8-node linear brick elements with reduced integration of type C3D8R is used to mesh the rock and soil in the ABAQUS software. The number of elements is 10240. The boundary of the bottom is fixed-branch boundary conditions, and the surround of the model is $\mathrm{U} 1=\mathrm{U} 2=\mathrm{UR} 3=0$. The contact property of tangential behavior and normal behavior is set in the surface-to-surface interaction, respectively. The FE model is shown in Figure 2(d).

The linear elastic constitutive model is adopted for a pile foundation, with the length and diameter being $100 \mathrm{~m}$ and $2 \mathrm{~m}$, respectively. Mohr-Coulomb plastic constitutive model and elastic model are adopted for the soil around the foundation. The Drucker-Prager constitutive model based on the relevant flow rule for karst caves is also adopted, which is often used in rock mechanics [28, 29]. Meanwhile, the expression method of DP criterion is easier and the efficiency of numerical calculation is higher compared with other criteria. In the actual FE calculation, the Drucker-Prager criterion is widely used in commercial software. The specific parameters are shown in Table 1.

The pile foundation and its surrounding soil and rocks have frictional contact, with the friction coefficient between pile foundation and the overlying soil and rocks being 0.5 and that between pile foundation and underlying rocks being 1.0. 


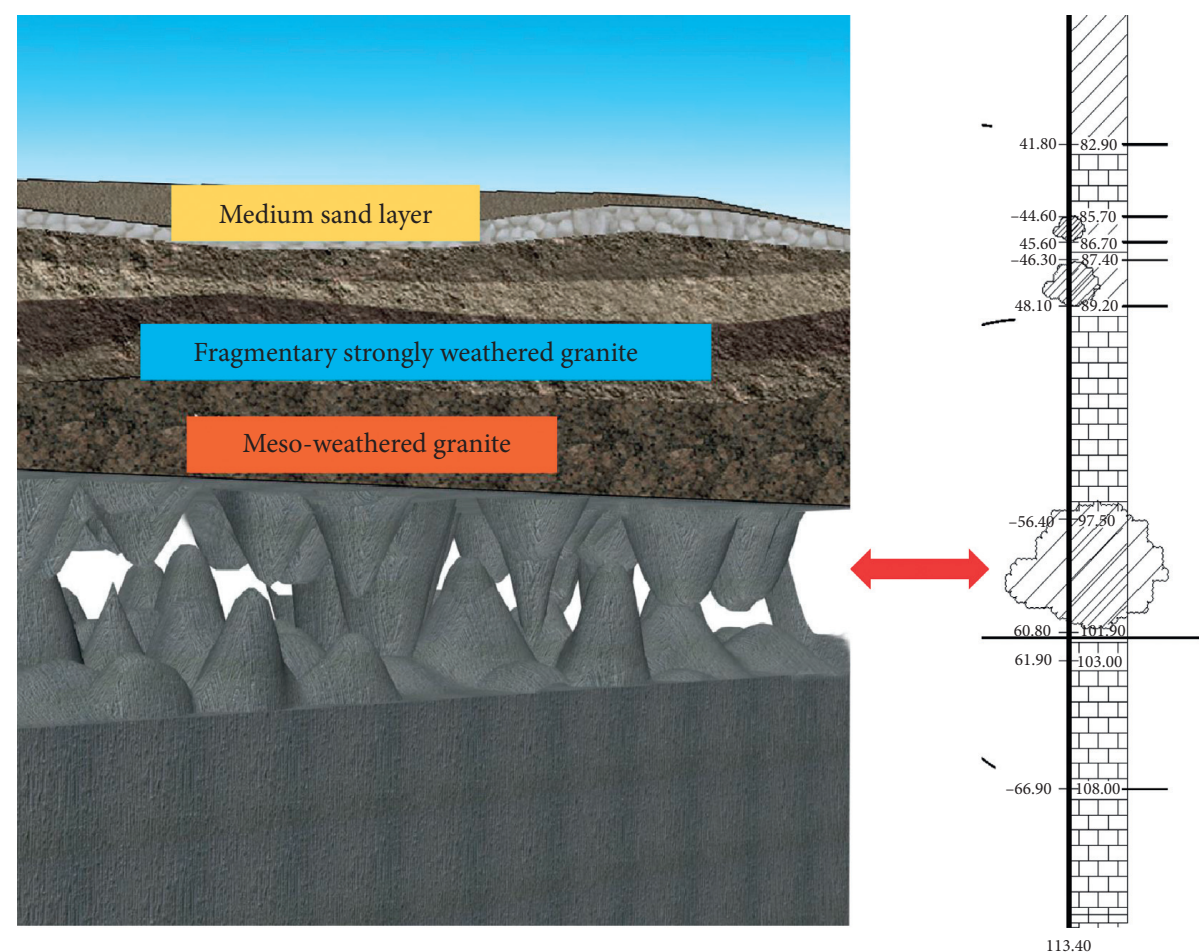

Figure 1: Typical three-dimensional karst cave and the cave distribution at the pile side.

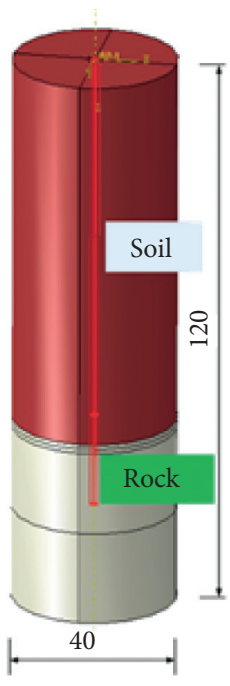

(a)

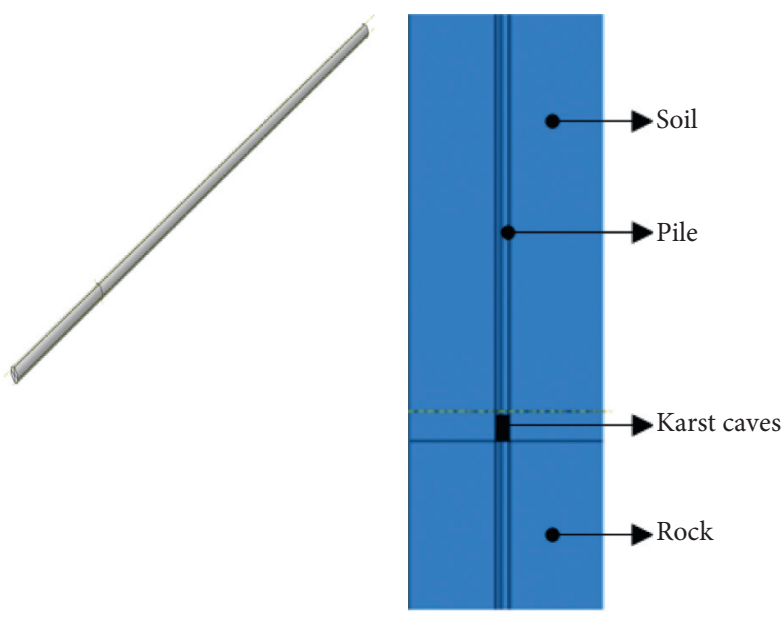

(b) (c)

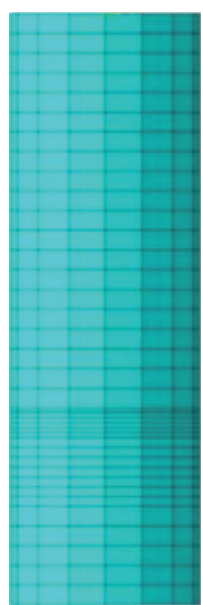

(d)

Figure 2: Analysis Model. (a) Geometric model. (b) Pile model. (c) Location of karst caves. (d) FE model.

TABLE 1: Material parameters.

\begin{tabular}{lccccc}
\hline & Density $\rho\left(\mathrm{kg} / \mathrm{m}^{3}\right)$ & Elasticity modulus $E(\mathrm{MPa})$ & Poisson's ratio $\mu$ & Cohesion $c(\mathrm{KPa})$ & Frictional angle $\varphi\left(^{\circ}\right)$ \\
\hline Equivalent soil & 1950 & 8 & 0.3 & 40 & 20.0 \\
Rock & 2680 & 14000 & 0.25 & 1000 & 44.5 \\
Pile & 2600 & 30000 & 0.1 & - & - \\
\hline
\end{tabular}




\section{Analytical Approach}

4.1. Influence of Karst Caves on the Static Bearing Characteristics of Super-Long Pile Foundations in Karst Areas. Based on the geological investigation data, the rectangular caves are chosen as objects. The height of karst caves " $\mathrm{H}$ " is $1 \mathrm{~m}$ and $5 \mathrm{~m}$, respectively, the side length " $\mathrm{D}$ " ranges from $4 \mathrm{~m}$ to $20 \mathrm{~m}$, and the roof thickness "T" ranges from $1 \mathrm{~m}$ to $10 \mathrm{~m}$. The bearing capacity of karst caves with different size combinations is calculated by the FE method. The location of the caves is shown in Figure 2(c), and the sizes of the caves are listed in Table 2.

The load-displacement curve of the pile foundation is extracted by applying horizontal and vertical displacement to the pile foundations at the mud surface. According to the Technical Code for Building Pile Foundation issued by the Ministry of Housing and Urban-Rural Development of the PRC, the bearing capacity can be derived from the applied load and the corresponding displacement relations. The applied horizontal load at the top of the pile foundation with the displacement of $10 \mathrm{~mm}$ is taken as the horizontal bearing capacity, while the applied vertical load at the top of the pile foundation with the displacement of $40 \mathrm{~mm}$ is taken as the vertical bearing capacity of the pile foundation.

4.2. Influence of Karst Caves on the Dynamic Characteristics of Super-Long Pile Foundation in Karst Areas (under Earthquake Conditions). According to the requirement of 7-degree seismic fortification in the karst area where the super-long piles are located in this project, the basic seismic acceleration is $0.10 \mathrm{~g}$, the characteristic period value is $0.40 \mathrm{~s}$, and the maximum time history of seismic acceleration used for analysis is $0.35 \mathrm{~m} / \mathrm{s}^{2}$. To conduct the study on seismic characteristics of the foundation [30-34], the time history curve of seismic acceleration used for calculation is the Ninghe-Tianjin ground motion, whose time history curve is shown in Figure 3.

\section{Results and Discussion}

\subsection{Influence of the Height of Karst Caves on Bearing Capacity}

5.1.1. Influence of the Height of Karst Caves on Horizontal Bearing Capacity. The relationships between the applied horizontal load and the corresponding displacement with different heights of karst caves are drawn in Figure 4. It can be seen from the figure that with small length and thin roof of the karst cave, and the height of the karst cave being 1 to $5 \mathrm{~m}$, the horizontal loads of pile foundations were almost the same when the same horizontal displacement occurs. With the length of the karst cave being big (about $20 \mathrm{~m}$ ) and the karst cave roof being thick $(10 \mathrm{~m})$, the horizontal bearing capacity of the pile foundation is slightly different when the horizontal displacement is greater than $0.06 \mathrm{~m}$.

The horizontal bearing capacity of pile foundations with different heights of karst caves is listed in Table 3.

By comparing the data of the horizontal bearing capacity of pile foundations, it is found that the height of the karst cave has little influence on the horizontal bearing capacity of
TABLE 2: Sizes of karst caves.

\begin{tabular}{lllccc}
\hline Variable & \multicolumn{3}{c}{ Size $(\mathrm{m})$} & & Abbreviation \\
\hline Height of cave & 1 & 5 & & & $\mathrm{H}$ \\
Side length of cave & 4 & 8 & 12 & 20 & $\mathrm{D}$ \\
Thickness of roof & 1 & 3 & 6 & 10 & $\mathrm{~T}$ \\
\hline
\end{tabular}

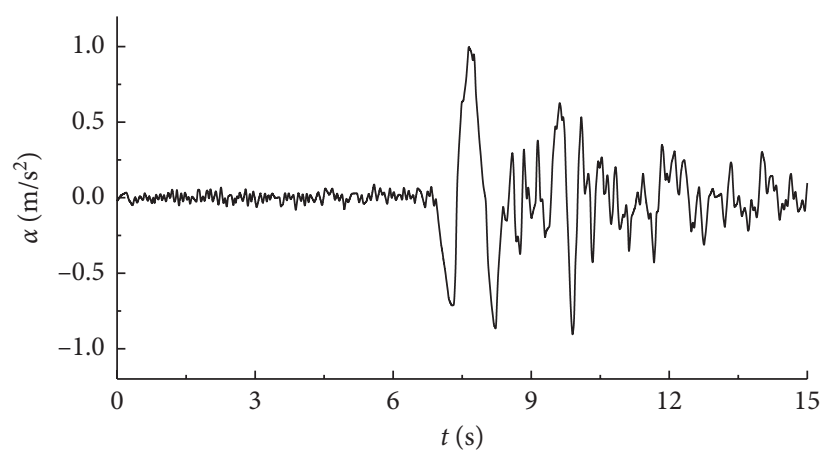

Figure 3: Time history curve of Tianjin ground motion.

pile foundations when the height of the karst cave is in the range of $1-5 \mathrm{~m}$.

5.1.2. Influence of the Height of Karst Caves on Vertical Bearing Capacity. Figure 5 shows the relationships between the applied vertical load and the corresponding displacement with different heights of karst caves. With the small length and thin roof of the karst cave, and the height of the karst cave being 1 to $5 \mathrm{~m}$, when the vertical displacement of pile foundations exceeds $0.1 \mathrm{~m}$, the smaller the height of karst cave is, the greater the vertical load becomes. With the length of the karst cave being big (about $20 \mathrm{~m}$ ) and the karst roof being thick, the height of the karst cave has little influence on the vertical load of pile foundations, and the vertical loads are almost the same.

The vertical bearing capacity of pile foundations with different heights of karst caves is listed in Table 4. By comparing the data of the vertical bearing capacity of pile foundations, it is found that the height of the karst cave has little influence on the vertical bearing capacity of pile foundations when the height of karst cave is in the range of $1-5 \mathrm{~m}$.

5.1.3. Influence of the Height of Karst Caves on Seismic Response. Figure 6 shows the seismic displacement time history at the top of pile foundations. By comparing the maximum values of the displacement at the top of pile foundations, it is illustrated that the height of karst caves has little impact on the seismic responses of the pile foundations.

\subsection{Influence of the Length of Karst Caves on the Bearing Capacity}

5.2.1. Influence of the Length of Karst Caves on Horizontal Bearing Capacity. Figure 7 shows relationships between the applied horizontal load and the corresponding displacement 


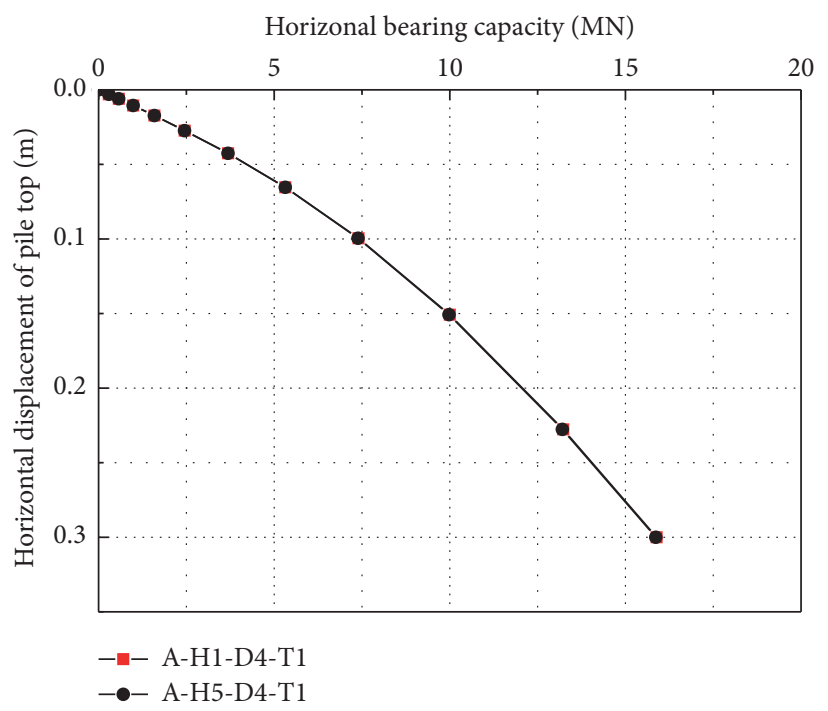

(a)

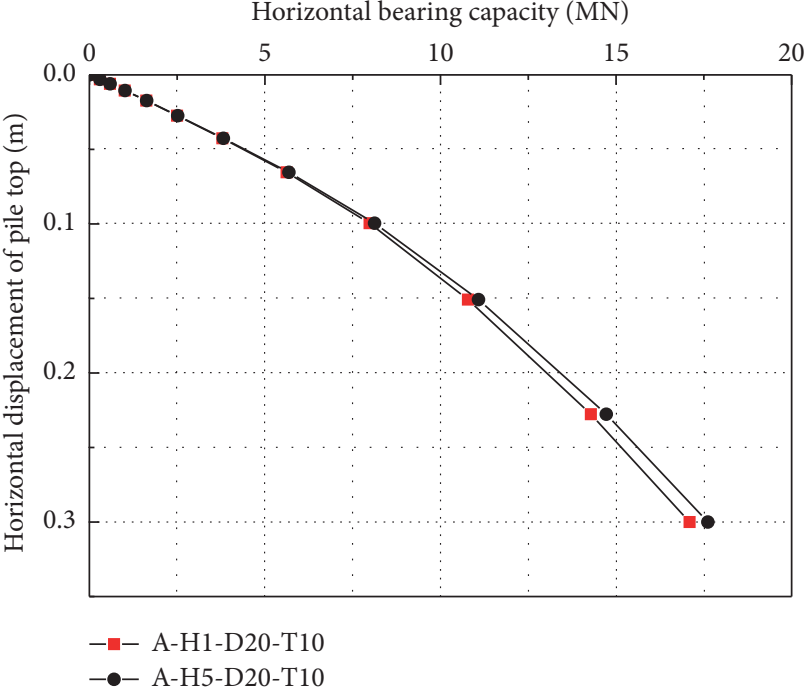

(b)

FiguRe 4: Relationships between the applied horizontal load and the corresponding displacement with different heights of karst caves.

TABLE 3: Horizontal bearing capacity with different heights of karst caves.

\begin{tabular}{lcccc}
\hline Case no. & Height of karst cave $(\mathrm{m})$ & Length of karst cave $(\mathrm{m})$ & Thickness of roof $(\mathrm{m})$ & Horizontal bearing capacity $(\mathrm{kN})$ \\
\hline A-H1-D4-T1 & 1 & 4 & 1 & 1371.06 \\
A-H5-D4-T1 & 5 & 4 & 1 & 1368.15 \\
A-H1-D20-T10 & 1 & 20 & 10 & 1534.76 \\
A-H5-D20-T10 & 5 & 20 & 10 & 1530.17 \\
\hline
\end{tabular}

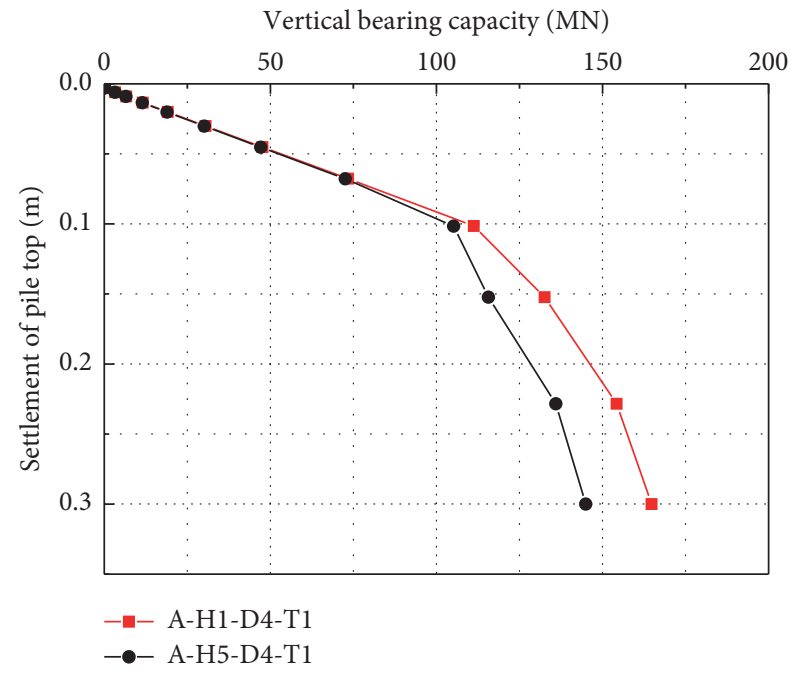

(a)

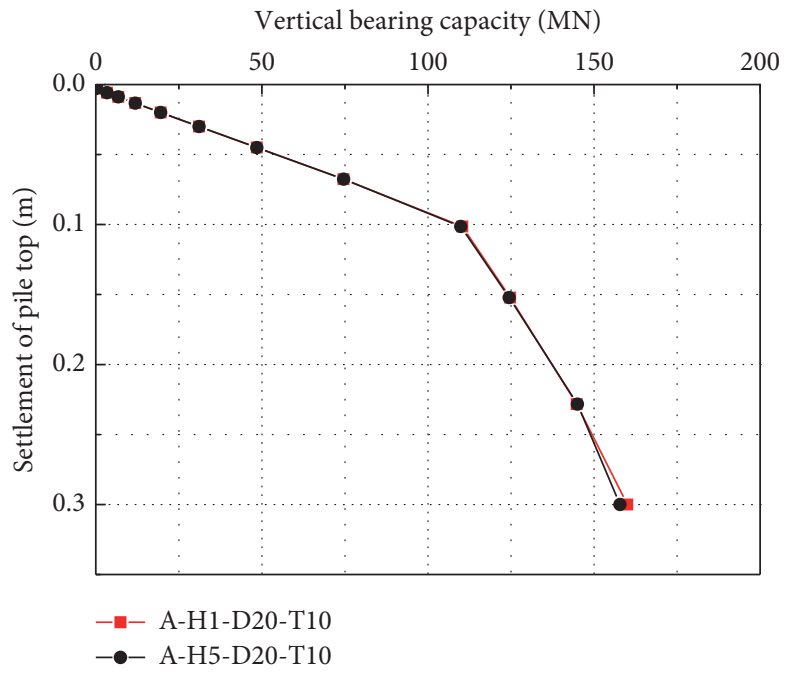

(b)

FIGURE 5: Relationships between the applied vertical load and the corresponding displacement with different heights of karst caves.

TABLE 4: Vertical bearing capacity with different heights of karst caves.

\begin{tabular}{lcccc}
\hline Case no. & Height of karst cave $(\mathrm{m})$ & Length of karst cave $(\mathrm{m})$ & Thickness of roof $(\mathrm{m})$ & Vertical bearing capacity $(\mathrm{kN})$ \\
\hline A-H1-D4-T1 & 1 & 4 & 1 & 37802.30 \\
A-H5-D4-T1 & 5 & 4 & 1 & 35767.62 \\
A-H1-D20-T10 & 1 & 20 & 10 & 37524.66 \\
A-H5-D20-T10 & 5 & 20 & 10 & 37472.35 \\
\hline
\end{tabular}




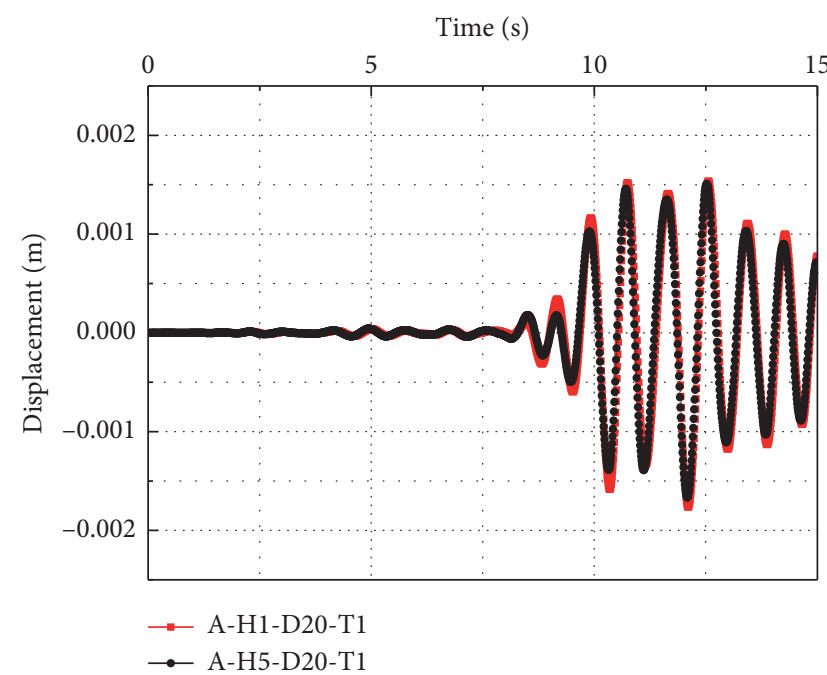

(a)

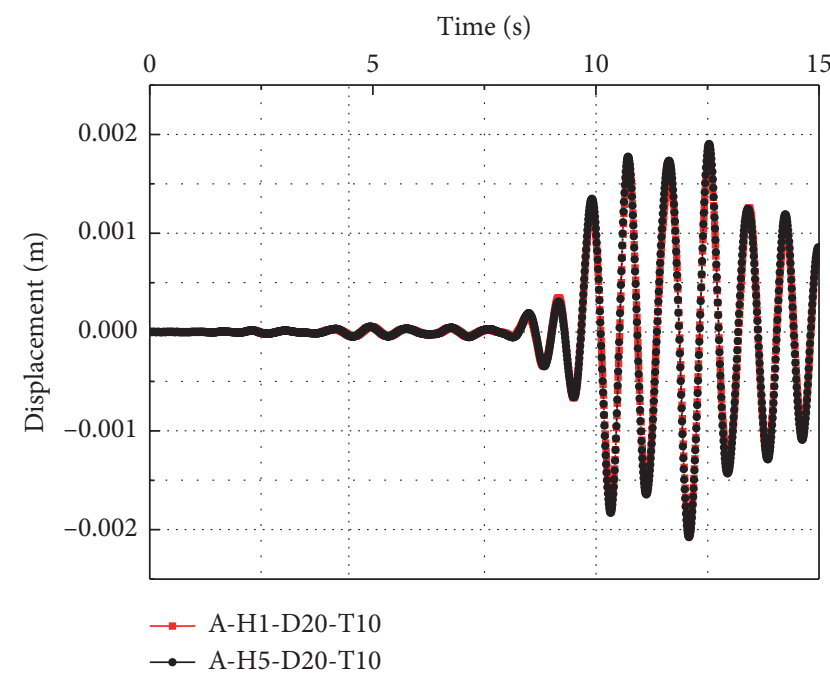

(b)

Figure 6: Seismic displacement time history at pile foundations top.

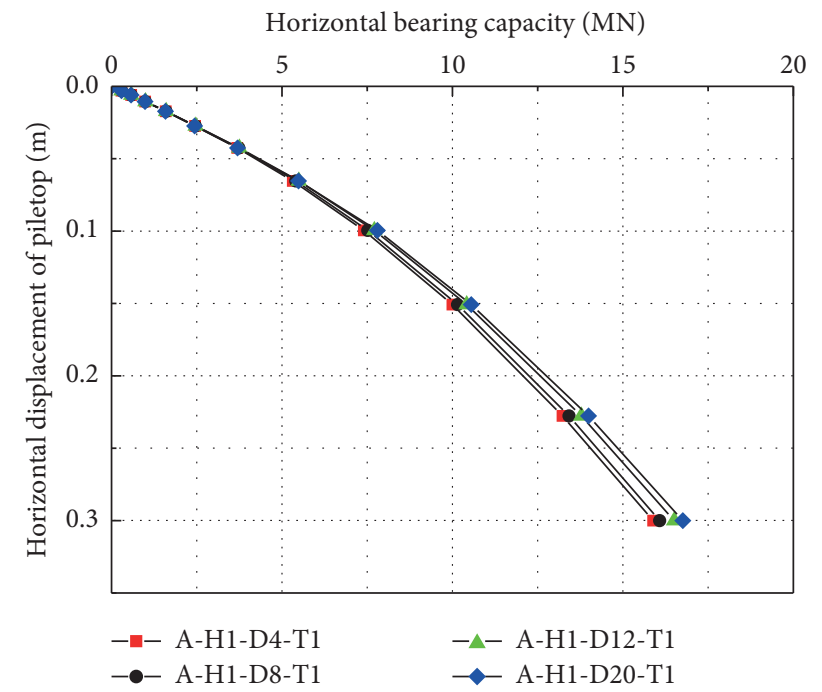

(a)

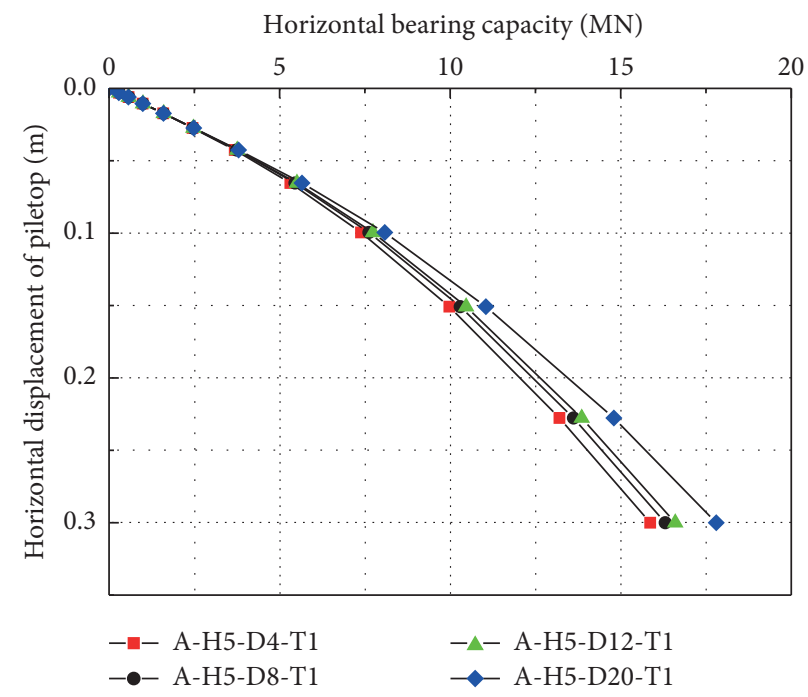

(b)

FIgure 7: Continued. 


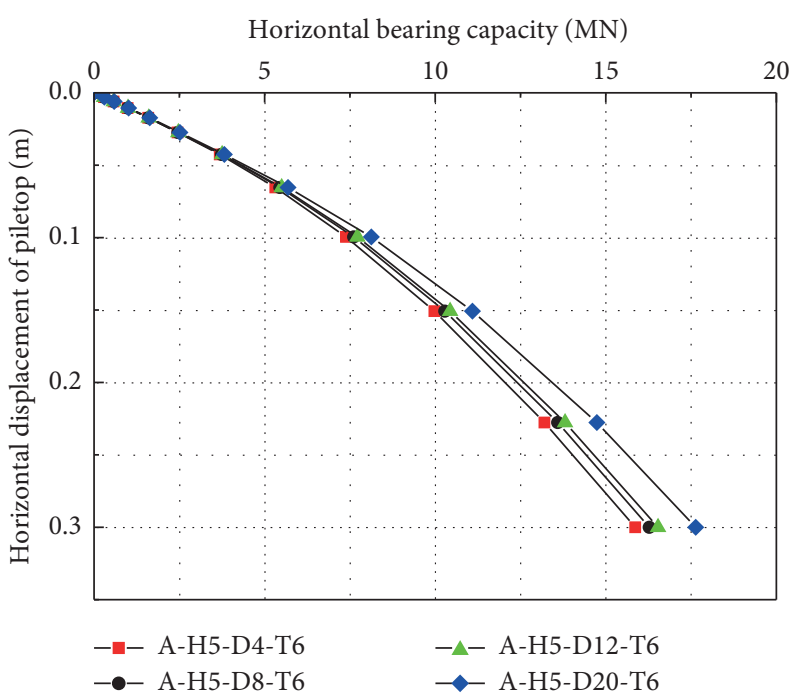

(c)

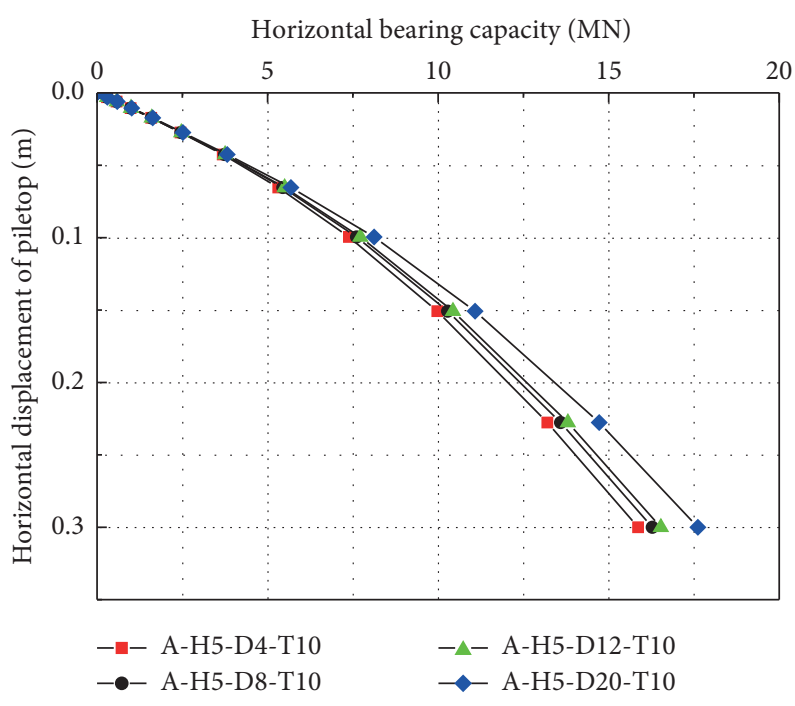

(d)

FigURE 7: Relationships between the applied horizontal load and the corresponding displacement with different lengths of karst caves. (a) H1-T-1. (b) H-5-T-1. (c) H-5-T-6. (d) H-5-T-10.

with different lengths of karst caves. When the horizontal displacement of the pile foundations is less than $0.05 \mathrm{~m}$, the influence of the length of karst caves on the horizontal loads of pile foundations is small. When the horizontal displacement of pile foundations is greater than $0.05 \mathrm{~m}$, the horizontal loads increase with the increase of the length of karst caves. Different heights of karst caves and thickness of karst cave roofs are selected and the comparison demonstrates the same rule.

Horizontal bearing capacity with different lengths of karst caves is listed in Table 5. It can be seen from Table 5 that when the height of the karst cave is $1 \mathrm{~m}$, the bearing capacity under the operating condition of H1-D20-T1 is $11.6 \%$ higher than that under H1-D4-T1. When the height of the karst cave is $5 \mathrm{~m}$, the bearing capacity under the operating condition of $\mathrm{H} 5-\mathrm{D} 20-\mathrm{T} 1$ is $8.5 \%$ higher than that under H5-D4-T1; the bearing capacity under H5-D20-T6 is $2.1 \%$ higher than that under H5-D4-T6; the bearing capacity under H5-D20-T10 is $2.1 \%$ higher than that under H5-D4-T10.

5.2.2. Influence of the Length of Karst Caves on Vertical Bearing Capacity. Relationships between the applied vertical load and the corresponding displacement with different lengths of karst caves are drawn in Figure 8. When the vertical displacement of pile foundations is less than $0.05 \mathrm{~m}$, the influence of the length of karst caves on the vertical loads of pile foundations is small. When the vertical displacement of pile foundations is greater than $0.05 \mathrm{~m}$, the vertical loads decrease with the increase of the length of karst caves. The influence of the length of karst caves on the vertical loads is analyzed under different operating conditions with different heights of karst caves and thickness of karst cave roofs, and the results demonstrate that the vertical loads decrease with the increase of the length of karst caves.
Table 6 shows the vertical bearing capacity of pile foundations with different lengths of karst caves. When the height of the karst cave is $1 \mathrm{~m}$, the bearing capacity under the operating condition of H1-D20-T1 is 7.5\% lower than that under H1-D4-T1. When the height of the karst cave is $5 \mathrm{~m}$, the bearing capacity under the operating condition of H5$\mathrm{D} 20-\mathrm{T} 1$ is $32.8 \%$ higher than that under H5-D4-T1.

5.2.3. Influence of the Length of Karst Caves on Seismic Response. Figure 9 shows the seismic displacement time history at the top of pile foundations. By comparing the maximum values of the displacement of the top of pile foundations, it is illustrated that the length of karst caves has little impact on the seismic loads born by the pile foundations.

\subsection{Influence of the Thickness of Roof on the Bearing Capacity}

5.3.1. Influence of the Thickness of Roof on the Horizontal Bearing Capacity. Figure 10 shows the relationships between the applied horizontal load and the corresponding displacement with different thicknesses of karst cave roofs. When the heights of karst caves are $1 \mathrm{~m}$ and $5 \mathrm{~m}$ and the length of karst caves is $4 \mathrm{~m}$, the calculation results under various operating conditions demonstrate that karst cave roofs of different thickness have little effect on the horizontal bearing capacity of pile foundations.

Table 7 shows the horizontal bearing capacity of pile foundations with different thicknesses of karst cave roofs. When the height of the karst cave is $1 \mathrm{~m}$, the horizontal bearing capacity of pile foundations is about $1371 \mathrm{kN}$, and when the height is $5 \mathrm{~m}$, the horizontal bearing capacity of pile foundations is about $1498.07 \mathrm{kN}$. 
TABLE 5: Horizontal bearing capacity with different lengths of karst caves.

\begin{tabular}{lcccc}
\hline Case no. & Height of karst caves $(\mathrm{m})$ & Length of karst caves $(\mathrm{m})$ & Thickness of roof $(\mathrm{m})$ & Horizontal bearing capacity $(\mathrm{kN})$ \\
\hline A-H1-D4-T1 & 1 & 4 & 1 & 1371.06 \\
A-H1-D8-T1 & 1 & 8 & 1 & $1368.15 \mathrm{~N}$ \\
A-H1-D12-T1 & 1 & 12 & 1 & 1534.76 \\
A-H1-D20-T1 & 1 & 20 & 1 & 1530.17 \\
A-H5-D4-T1 & 5 & 4 & 1 & 1368.15 \\
A-H5-D8-T1 & 5 & 8 & 1 & 1517.14 \\
A-H5-D12-T1 & 5 & 12 & 1 & 1520.20 \\
A-H5-D20-T1 & 5 & 20 & 1 & 1485.22 \\
A-H5-D4-T6 & 5 & 4 & 6 & 1498.07 \\
A-H5-D8-T6 & 5 & 8 & 6 & 1517.53 \\
A-H5-D12-T6 & 5 & 12 & 6 & 1512.91 \\
A-H5-D20-T6 & 5 & 20 & 6 & 1529.48 \\
A-H5-D4-T10 & 5 & 4 & 10 & 1498.06 \\
A-H5-D8-T10 & 5 & 8 & 10 & 1386.74 \\
A-H5-D12-T10 & 5 & 12 & 10 & 1521.98 \\
A-H5-D20-T10 & 5 & 20 & 1530.17 \\
\hline
\end{tabular}

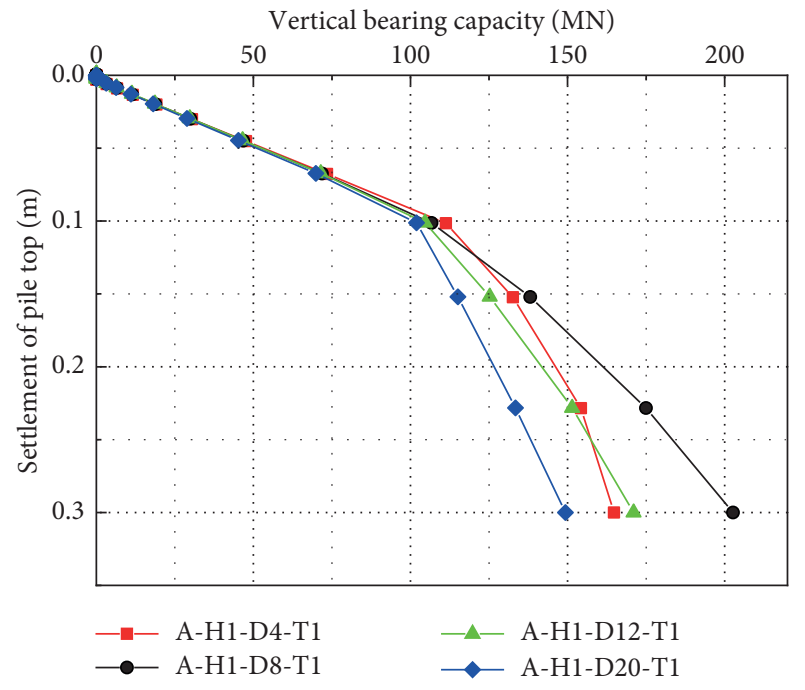

(a)

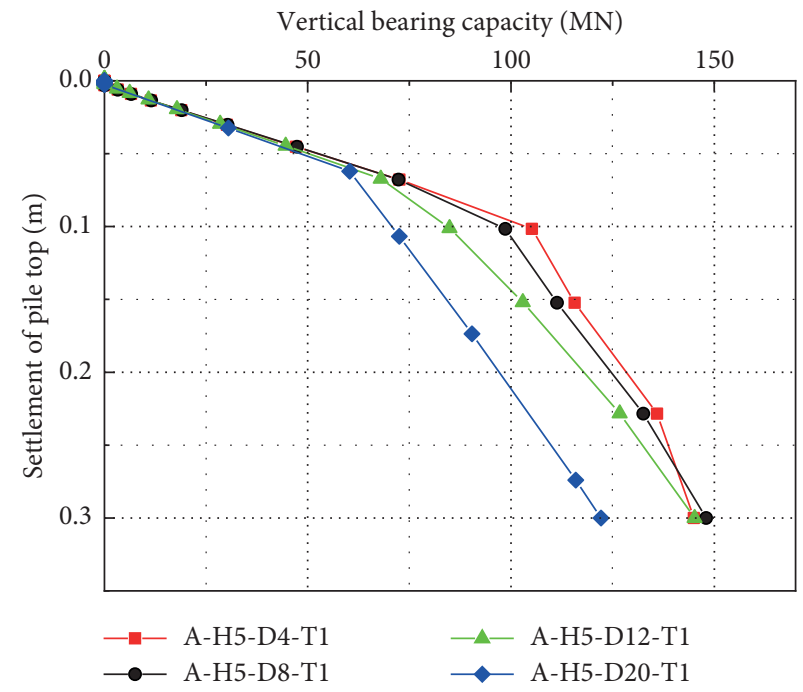

(b)

FIGURE 8: Relationships between the applied vertical load and the corresponding displacement with different lengths of karst caves. (a) H-1T-1. (b) H-5-T-1.

TABLE 6: Vertical bearing capacity with different lengths of karst caves.

\begin{tabular}{lcccc}
\hline Case no. & Height of karst caves $(\mathrm{m})$ & Length of karst caves $(\mathrm{m})$ & Thickness of roof $(\mathrm{m})$ & Vertical bearing capacity $(\mathrm{kN})$ \\
\hline A-H1-D4-T1 & 1 & 4 & 1 & 37802.30 \\
A-H1-D8-T1 & 1 & 8 & 1 & 38024.36 \\
A-H1-D12-T1 & 1 & 12 & 1 & 36728.05 \\
A-H1-D20-T1 & 1 & 20 & 1 & 34967.37 \\
A-H5-D4-T1 & 5 & 4 & 1 & 35767.62 \\
A-H5-D8-T1 & 5 & 8 & 1 & 34963.77 \\
A-H5-D12-T1 & 5 & 12 & 1 & 32573.91 \\
A-H5-D20-T1 & 5 & 20 & 1 & 24036.68 \\
\hline
\end{tabular}



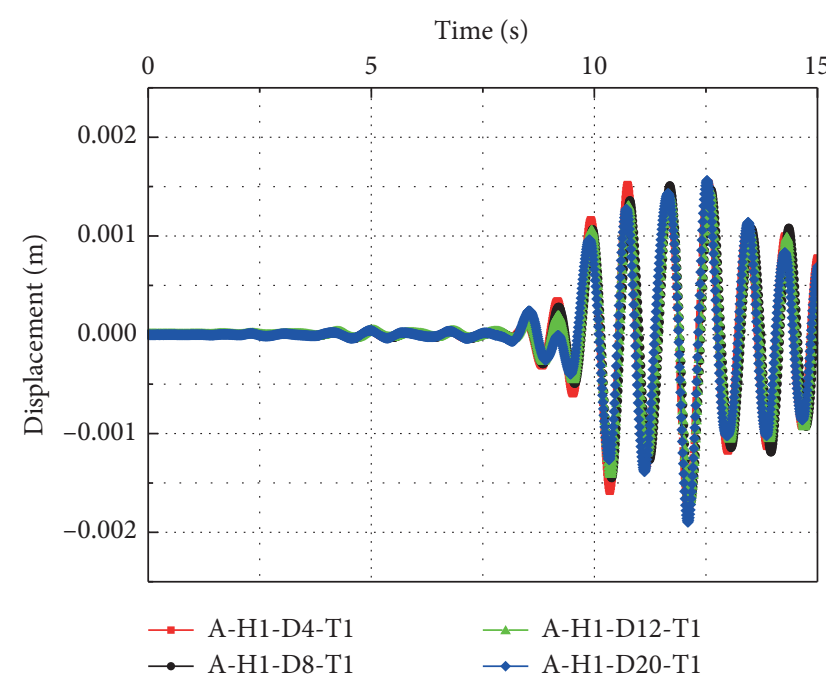

(a)

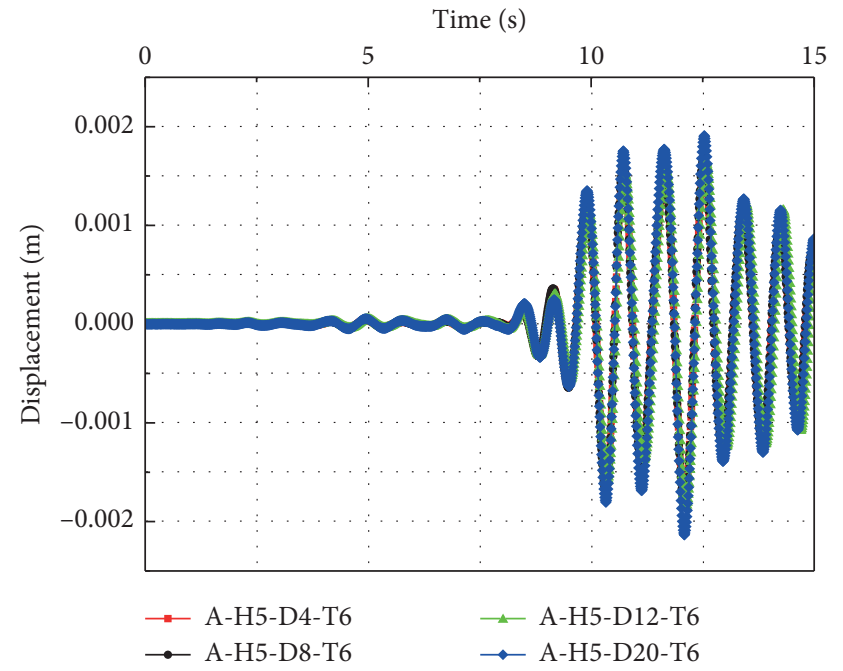

(c)

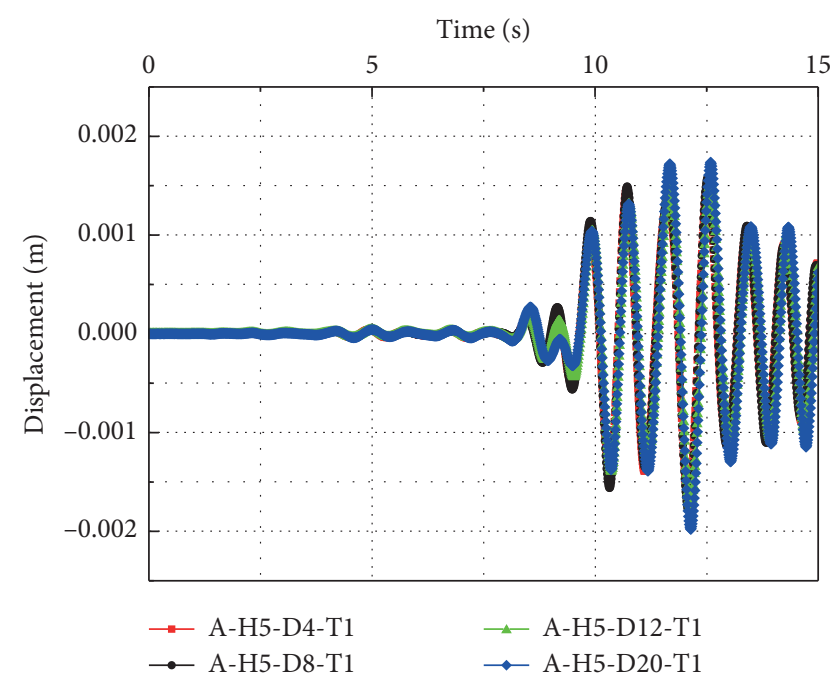

(b)

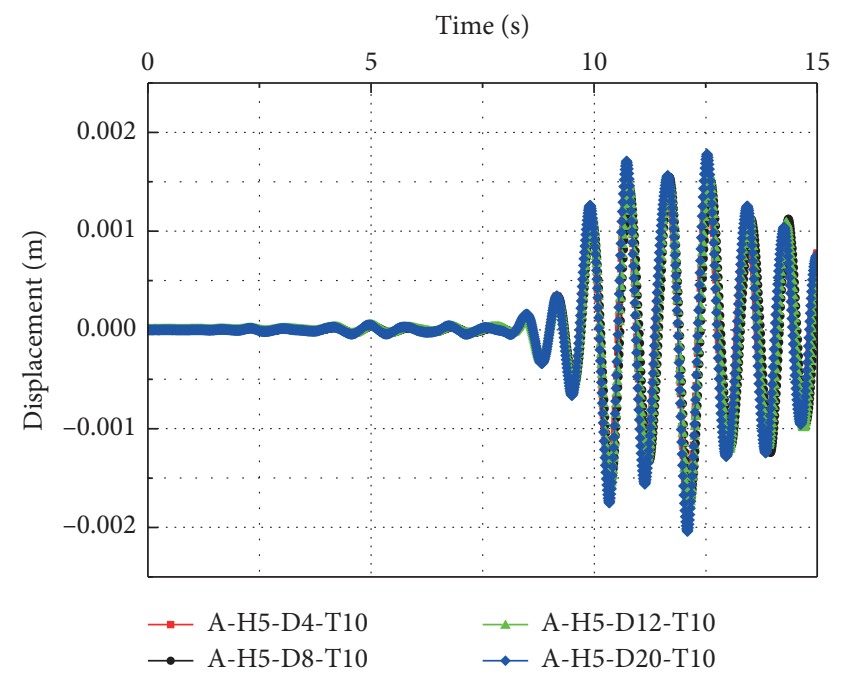

(d)

Figure 9: Seismic displacement time history at pile foundations top with different lengths of karst caves. (a) H-1-T-1. (b) H-5-T-1. (c) H-5T-6. (d) H-5-T-10.

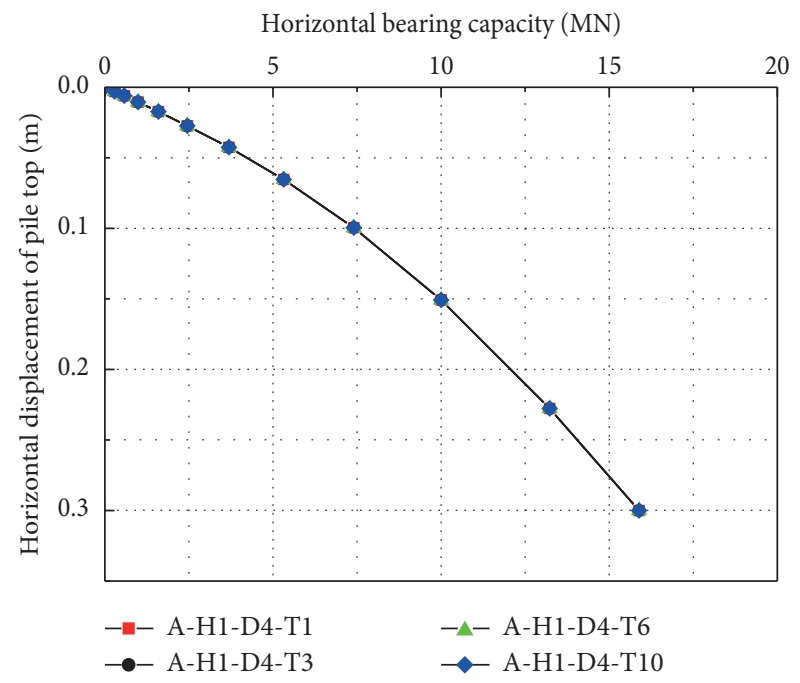

(a)

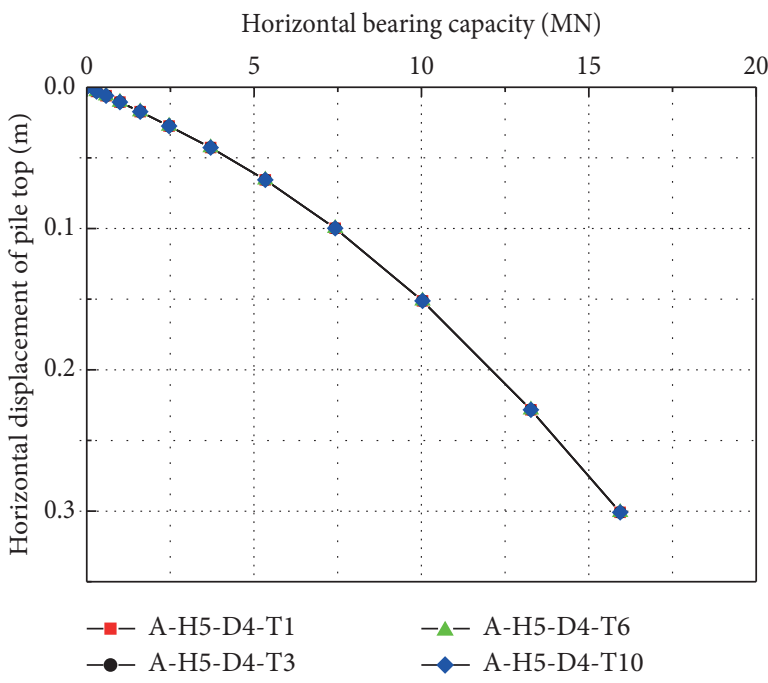

(b)

Figure 10: Relationships between the applied horizontal load and the corresponding displacement with thickness of karst cave roofs. 
TABLE 7: Horizontal bearing capacity with thickness of karst cave roofs.

\begin{tabular}{lcccc}
\hline Case no. & Height of karst caves $(\mathrm{m})$ & Length of karst caves $(\mathrm{m})$ & Thickness of roofs $(\mathrm{m})$ & Horizontal bearing capacity $(\mathrm{kN})$ \\
\hline A-H1-D4-T1 & 1 & 4 & 1 & 1371.05 \\
A-H1-D4-T3 & 1 & 4 & 3 & 1371.10 \\
A-H1-D4-T6 & 1 & 4 & 6 & 1371.06 \\
A-H1-D4-T10 & 1 & 4 & 10 & 1371.06 \\
A-H5-D4-T1 & 5 & 4 & 1 & 1498.07 \\
A-H5-D4-T3 & 5 & 4 & 3 & 1498.07 \\
A-H5-D4-T6 & 5 & 4 & 6 & 1498.07 \\
A-H5-D4-T10 & 5 & 4 & 10 & 1498.06 \\
\hline
\end{tabular}

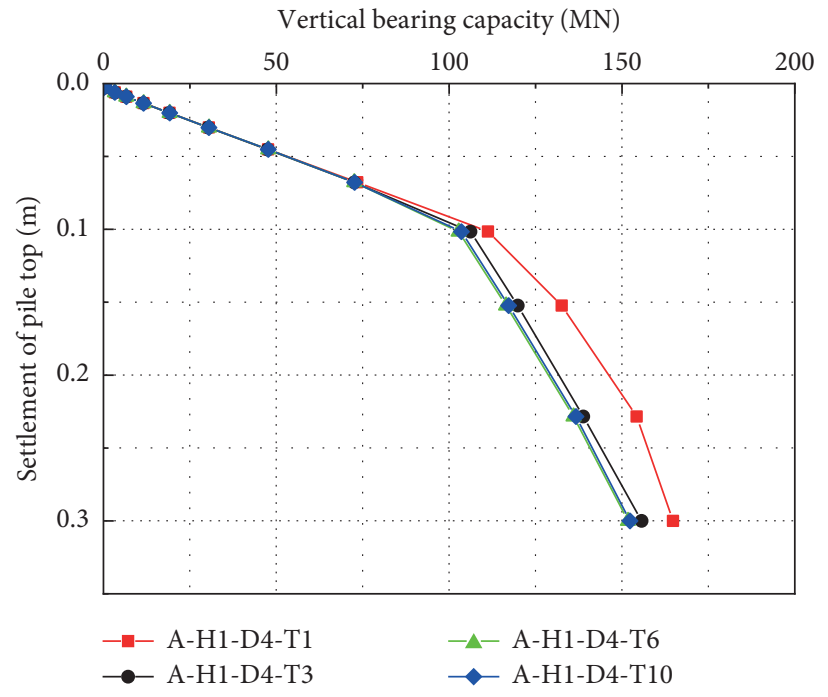

(a)

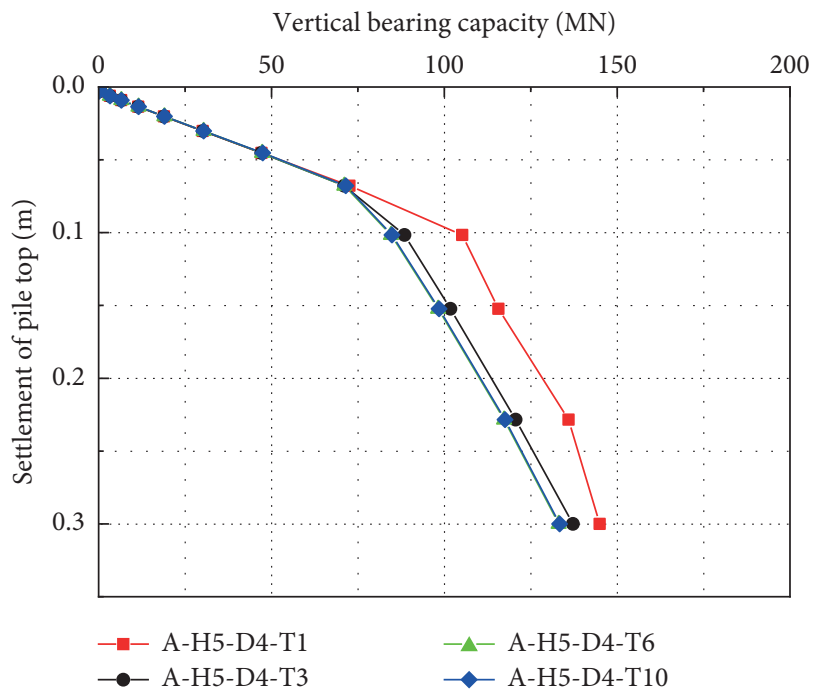

(b)

FIGURE 11: Relationships between applied vertical load and corresponding displacement with different roof thickness.

TABLE 8: Vertical bearing capacity with thickness of karst cave roofs.

\begin{tabular}{lcccc}
\hline Case no. & Height of karst caves $(\mathrm{m})$ & Length of karst caves $(\mathrm{m})$ & Thickness of roofs $(\mathrm{m})$ & Vertical bearing capacity $(\mathrm{kN})$ \\
\hline A-H1-D4-T1 & 1 & 4 & 1 & 37802.30 \\
A-H1-D4-T3 & 1 & 4 & 3 & 36204.07 \\
A-H1-D4-T6 & 1 & 4 & 6 & 35785.32 \\
A-H1-D4-T10 & 1 & 4 & 10 & 35889.62 \\
A-H5-D4-T1 & 5 & 4 & 1 & 35767.62 \\
A-H5-D4-T3 & 5 & 4 & 3 & 33225.08 \\
A-H5-D4-T6 & 5 & 4 & 6 & 32768.56 \\
A-H5-D4-T10 & 5 & 4 & 10 & 32850.30 \\
\hline
\end{tabular}

\subsubsection{Influence of the Thickness of Roof on Vertical Bearing} Capacity. Figure 11 shows the displacement of vertical loads of pile foundations under different thicknesses of karst cave roofs. When the vertical displacement of pile foundations is less than $0.07 \mathrm{~m}$, the thickness of karst cave roofs has little influence on the vertical loads of pile foundations. When the vertical displacement of pile foundations is more than $0.07 \mathrm{~m}$, the vertical loads decrease with the increase in the thickness of karst cave roofs. The influence of the thickness of karst cave roofs on vertical loads is analyzed under different operating conditions with heights of karst caves, and the comparison results demonstrate that the vertical loads decrease with the increase of the thickness of karst cave roofs.
Table 8 shows the vertical bearing capacity of pile foundations with different thicknesses of karst cave roofs. The bearing capacity under the operating condition of H1D4-T10 is $5.1 \%$ less than that under H1-D4-T1, and the bearing capacity under the operating condition of H5-D4$\mathrm{T} 10$ is $8.2 \%$ less than that under H1-D4-T1. It is illustrated that the thicker the karst cave roof is, the smaller the vertical bearing capacity of pile foundation becomes.

5.3.3. Influence of the Thickness of Roof on Seismic Response. Figure 12 shows seismic displacement time history at the top of the pile foundations. By comparing the maximum values of displacement of the top of the pile foundations, it 


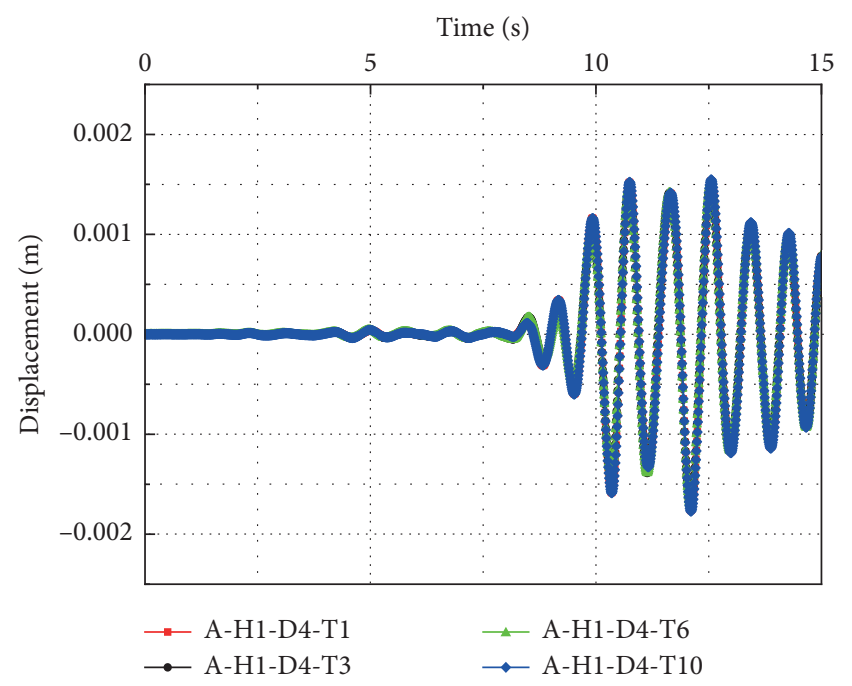

(a)

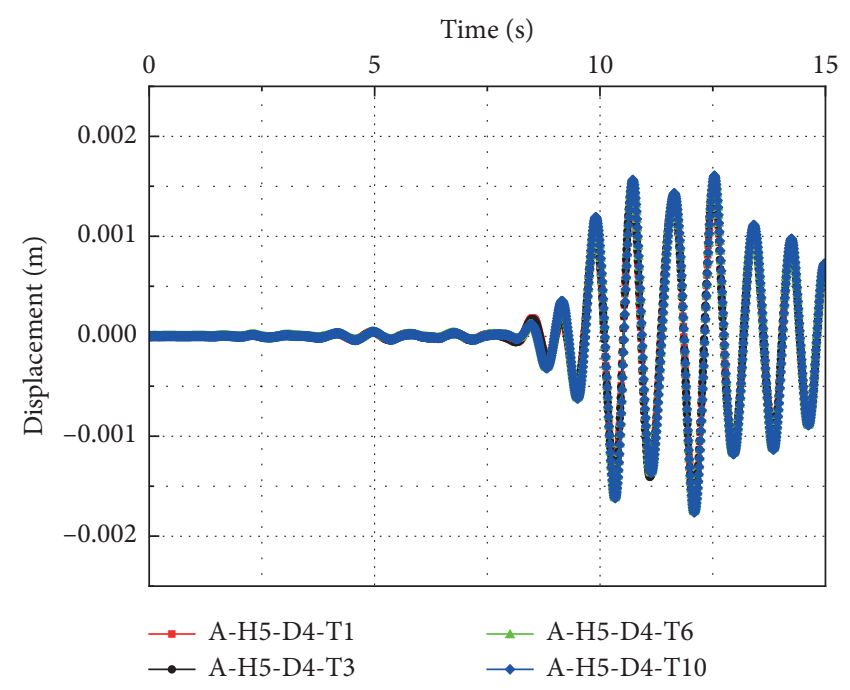

(b)

FIGURE 12: Seismic displacement time history at the top of pile foundations with thickness of karst cave roofs.

is illustrated that the thickness of the karst cave roof has little impact on the seismic loads born by the pile foundations.

\section{Conclusions}

The influence of length, height, and roof thickness of karst caves on the horizontal and vertical bearing capacity of pile foundations under seismic loads have been analyzed, which can be an important with reference to the design and construction of the pile foundation of bridges in karst areas. The following conclusions can be drawn:

(1) When the horizontal displacement at the top of pile foundations is less than $0.05 \mathrm{~m}$, the length of karst caves has little influence on the horizontal load of the foundations; when the horizontal displacement is more than $0.05 \mathrm{~m}$, the horizontal load increases with the increase of the length of karst caves

(2) When the vertical displacement of pile foundations is less than $0.07 \mathrm{~m}$, the thickness of karst cave roofs has little impact on the vertical load of foundations; when the vertical displacement of pile foundations is more than $0.07 \mathrm{~m}$, the vertical load decreases with the increase in the thickness of the roof

(3) The height of karst caves has little influence on the horizontal and vertical bearing capacity of pile foundations

(4) The existence of karst caves has little effect on the dynamic response of pile foundations

\section{Data Availability}

The data used to support the findings of this study are included within the article.

\section{Conflicts of Interest}

The authors declare that there are no conflicts of interest regarding the publication of this paper.

\section{Acknowledgments}

The authors thank the following organizations and projects for their support and sponsorship with this paper: Project of Science and Technology Plan for Housing and Urban-Rural Construction of Shandong Province (No. 2017-K2-004), Project of Science and Technology Plan of College of 2018 hosted by the Education Department of Shandong Province (Analysis of Pile Foundation Bearing Mechanism in Karst Areas and Applied Research of Treatment Technology in Construction), Project of the Coordination and Innovation Center of Disaster Prevention and Mitigation of Civil Structures of Institutions of Higher Education of Shandong Province of 2019 (No. XTP201912), and Shandong Luqiao Group (the Fourth Batch of Technological Innovation Projects of Shandong Province of 2016; the Second Batch of Technological Innovation Projects of Shandong Province of 2018).

\section{References}

[1] G. Tang, Settlement Calculation and Stability Analysis of Bridge Pile Foundation in Beaded Karst Areas, Hunan University, Changsha, China, 2013.

[2] J. Fan, Buckling Stability Analysis of Super-long Foundation Piles in Karst Areas, Central South University of Forestry and Technology, Changsha, China, 2013.

[3] X. He, Study on Design and Calculation Method of Pile Foundation Considering the Difference between Foundation and Foundation Pile in Karst Areas, Hunan University, Changsha, China, 2013.

[4] W. Yang, Analysis of Bearing Behavior of Deep-Water Large Diameter Pile Foundation in Multi-Layer Karst Areas, Central 
South University of Forestry and Technology, Changsha, China, 2012.

[5] X. Shi, "Study on stability of roof of concealed karst cave under pile foundation load in karst area," Institute of Rock and Soil Mechanics, Chinese Academy of Sciences, Beijing, China, 2005.

[6] M. Zhao, Y. Lei, and R. Zhang, "Study on punching shear failure mode and safe thickness of pile foundation in karst area," Rock and Soil Mechanics, vol. 33, no. 2, pp. 524-530, 2012.

[7] S. Chen, X. Xu, Z. Dai, and H. Xu, "Numerical study on the stress of pile foundation influenced by the beaded karst," in Proceedings of the 6th International Conference on Information Engineering for Mechanics and Materials, Hohhot, China, 2016.

[8] S. Erhan and M. Dicleli, "Effect of dynamic soil-bridge interaction modeling assumptions on the calculated seismic response of integral bridges," Soil Dynamics and Earthquake Engineering, vol. 66, pp. 42-55, 2014.

[9] L. J. Prendergast and K. Gavin, "A comparison of initial stiffness formulations for small-strain soil-pile dynamic Winkler modelling," Soil Dynamics and Earthquake Engineering, vol. 81, pp. 27-41, 2016.

[10] W. Wu, H. Liu, M. H. El Naggar, G. Mei, and G. Jiang, "Torsional dynamic response of a pile embedded in layered soil based on the fictitious soil pile model," Computers and Geotechnics, vol. 80, pp. 190-198, 2016.

[11] H. Torabi and M. T. Rayhani, "Equivalent-linear pile head impedance functions using a hybrid method," Soil Dynamics and Earthquake Engineering, vol. 101, pp. 137-152, 2017.

[12] L. Tang, X. Ling, X. Zhang, L. Su, C. Liu, and H. Li, "Response of a RC pile behind quay wall to liquefaction-induced lateral spreading: a shake-table investigation," Soil Dynamics and Earthquake Engineering, vol. 76, pp. 69-79, 2015.

[13] H. Suzuki, K. Tokimatsu, and K. Tabata, "Factors affecting stress distribution of a $3 \times 3$ pile group in dry sand based on three-dimensional large shaking table tests," Soils and Foundations, vol. 54, no. 4, pp. 699-712, 2014.

[14] G. Su, Experimental Study on Vertical Bearing Behavior of Bridge Foundation Pile in Multilayer Karst Region, Central South University of Forestry and Technology, Changsha, China, 2015.

[15] Y. Tao, “Three-dimensional numerical simulation analysis and research on follow-up of long casing of complex karst pile foundation," Journal of Shijiazhuang Tiedao University, vol. 26, no. 1, pp. 76-81, 2013.

[16] F. Zhu, Numerical Analyzing Research on Bearing Capacity of Bridge Pile Foundation in Karst Areas of Jiangxi Province, Nanchang University, Nanchang, China, 2015.

[17] J. An, Numerical Stimulation and Analysis of the Influence of Pile-Side Karst Caves with Large Diameters on Vertical Bearing Characteristics in Karst Areas, Chang'an University, Xi'an, China, 2013.

[18] S. He and G. Lu, "Study on load transfer characteristic of rocksocketed pole," Rock and Soil Mechanics, vol. 28, no. 12, pp. 2598-2602, 2007.

[19] M. Feng, Study on Bearing Mechanism and Test of Bridge Pile Foundations in Karst Areas, Hunan University, Changsha, China, 2014.

[20] C. He, C. Gong, and D. Ji, "Analysis of influence of karst cave characteristics on bearing capacity of pile foundations in karst areas," Journal of Huaiyin Institute of Technology, vol. 15, no. 1, pp. 78-81, 2006.
[21] C. T. Wong, K. P. Yim, M. K. Leung, and S. C. Fung, "Rocksocketed large diameter bored pile and geophysical survey in cavernous karst area: Tin Shui Wai public library cum indoor recreation centre," Procedia Engineering, vol. 14, pp. 17441751, 2011.

[22] K. Elbaz, S.-L. Shen, Y. Tan, and W.-C. Cheng, "Investigation into performance of deep excavation in sand covered karst: a case report," Soils and Foundations, vol. 58, no. 4, pp. 1042 1058, 2018.

[23] J. Niu, I. A. Oyediran, D. Liu et al., "Quantitative foundation stability evaluation of urban karst area: case study of Tangshan, China," Soils and Foundations, vol. 55, no. 3, pp. 493503, 2015.

[24] W. Wang, "Study on bearing mechanism of pile penetration karst caves and cavern treatment technology in karst area," Doctoral Dissertation, Beijing Jiaotong University, Beijing, China, 2019.

[25] P. Meymand, "Shaking table scale model tests of nonlinear soil-pile-superstructure interaction in soft clay," Doctoral Dissertation, University of California, Berkeley, CA, USA, 1998.

[26] H. Zhuang, "Study on nonlinear dynamic soil-underground structure interaction and its large-size shaking table test," Doctoral Dissertation, Nanjing University of Technology, Nanjing, China, 2006.

[27] X. Du, Z. Xu, C. Xu, Y. Li, and J. Jiang, "Research on time history analysis method of soil-underground structure system based on equivalent linear method," Chinese Journal of Geotechnical Engineering, vol. 40, no. 12, pp. 2155-2163, 2018.

[28] C. Deng, G. He, and Y. Zheng, "Studies on Drucker-Prager yield criterions based on $\mathrm{M}-\mathrm{C}$ yield criterion and application in geotechnical engineering," Chinese Journal of Geotechnical Engineering, vol. 28, no. 6, pp. 735-739, 2006.

[29] X. Wang, M. Chen, X. Chang, W. Zhou, and Z. Yuan, "Studies of application of Drucker-Prager yield criteria to stability analysis," Rock and Soil Mechanics, vol. 30, no. 12, pp. 3733-3738, 2009.

[30] R. Zhang, "Study of numerical simulation of dynamic response of rock-socketed pile foundation under horizontal seismic loading," East China Highway, vol. 3, pp. 29-30, 2016.

[31] Z. Han and A. Ye, "Analysis of sensitivity of seismic capability value of pile foundation of groups of bridges," Journal of Shenzhen University Science of Engineering, vol. 27, no. 4, pp. 452-458, 2010.

[32] D. Zhang and A. Ye, "A review of experimental researches on seismic performance of bridge pile foundation," Structural Engineers, vol. 26, no. 5, pp. 157-163, 2010.

[33] L. Wu, "Analysis of elastoplastic seismic response under the pile-soil-superstructure coupling action," Journal of Chongqing Jiaotong University (Natural Science), vol. 4, pp. 621-624, 2013.

[34] C. Guo and Z. Peng, "Analysis of dynamic effect of frictional resistance of single pile in building aseismicity," Journal of Hunan University (Natural Sciences), vol. 42, no. 3, pp. 57-62, 2015. 